\title{
Society Differentiation, Can Human Rights be Protected?: Critical Study of the Tribes Castration on Community (Case Study of Laporo Buton)
}

\author{
Birkah Latif $^{1}$, Agung Syaputra ${ }^{2}$, Nurul Zashkia ${ }^{3}$, Rifda Aprilia Rusfayanti ${ }^{4}$ \\ 1Faculty of Law, Hasanuddin University, Email: birkahlatif@gmail.com \\ 2Faculty of Law, Hasanuddin University, Email: agung121324@gmail.com \\ ${ }^{3}$ Faculty of Law, Hasanuddin University, Email: zashkiatasrim1400@yahoo.com \\ ${ }^{4}$ Faculty of Law, Hasanuddin University, Email: rifdaapriliarusfayanti@gmail.com
}

\begin{tabular}{l}
\hline Info Artikel \\
\hline Masuk: $7^{\text {th }}$ June 2019 \\
Diterima: $26^{\text {th }}$ July 2019 \\
Terbit: $31^{\text {st }}$ July 2109 \\
Keywords: \\
human right; discrimination; \\
tribe \\
Corresponding Author: \\
Birkah Latif. Email: \\
birkahlatif@gmail.com \\
DOI: \\
10.24843/JMHU.2019.v08.i02. \\
p01
\end{tabular}

\begin{abstract}
In administering a country based on the rule of law, the main element is the enforcement of human rights. In every country still found, there are discriminatory discriminations against citizens, both those that are needed from state actions, and those needed from the community. With the existence of a convention on the protection of special human rights, the state must approve and protect its citizens. Problems that occur in pluralistic Indonesia is in preventing the social life in community. The research method of the paper is an empirical juridical method to answer whether Indonesia handling the enforcement of human rights and review human rights protection in Indonesia when dealing with communities which holding customary law in their community. If the practice of customary law turns out there is discriminatory practices against the tribe or sub-tribe in it, then how does the state uphold human rights?
\end{abstract}

\section{Introduction}

Human rights are inherent in humans, where humans are also blessed with various advantages in the form of mind and conscience. Human rights are universal, which means beyond national and national boundaries. Applies to every human being both disabled and vice versa, differences over fellow human beings without distinguishing their skin color, gender, age, cultural background and religion or belief.

As a norm intended for the recognition of the rights of all people, each individual or group needs to recognize the basics of human rights and also implement them.

Then what about the modern era where there are still differences in treatment due to the existence of unofficial structures that have been built from the past. The legacy of the past is still scattered in the life of the community and even becomes a stigma that tends to be negative towards certain groups or tribes that ultimately leave social problems and even to violate the law (including discriminatory actions).

Some examples in community life that experience different treatment and discriminatory actions can be seen in several cases in the world. this then causes a reaction to acts of discrimination. The opinion regarding discrimination is: 
...racial discrimination refers to unequal treatment of persons or groups on the basis of their race or ethnicity. In defining racial discrimination, many scholars and legal advocates distinguish between differential treatment and disparate impact, creating a two-part definition: Differential treatment occurs when individuals are treated unequally because of their race. ${ }^{1}$

All citizens are at the same time in the law and are entitled to protection against any form of racial and ethnic discrimination. The existence of racial and ethnic discrimination in social life is an obstacle to the relationship of kinship, brotherhood, friendship, peace, harmony, security, and life with a livelihood among citizens who always coexist.

One of the foundations of international rules aimed at protecting human rights and eliminating discrimination is the International Convention on the Elimination of All Forms of Racial Discrimination, abbreviated ICERD) is a human rights convention that requires its members to eliminate racial discrimination and develop understanding among all races.

The condition of the Indonesian nation, which has multiple dimensions in various aspects of life, such as culture, religion, race, and ethnicity, has the potential to cause conflict. To guarantee the absence of conflict and discrimination, the Government of Indonesia established a Law No. 40 of 2008 concerning the Elimination of Racial and Ethnic Discrimination.

Based on this, this paper wants to see whether Indonesia has been able to protect human rights and whether a pluralistic Indonesian society can support the upholding of human rights and specifically prevent discrimination in social life (at the level of regional government especially in the smallest or sub-tribal groups).

\section{Research Methods}

The problems that will be studied by researchers are social related to the issue of equality of law, especially human rights. This paper is directed as an empirical legal which in other words is a type of sociological legal research and can also be referred to as field research, which is to examine the applicable legal provisions and what happens in reality in the community. Empirical research is unwritten positive law research on the behavior of community members in the relationship of community life.

An empirical study conducted on the actual conditions or real conditions that occur in the community intending to find out and find the facts and data needed, after the data needed is collected then leads to the identification of problems which ultimately lead to solving problems.

The author chose to use a qualitative approach to determine how to find, collect, process and analyze data from the research results, namely research that gave a careful description of the forms of discrimination received by the Laporo people in the community of Buton Regency.

1 Devah Pager and Hana Shepherd, (2008). The sociology of discrimination: Racial discrimination in employment, housing, credit, and consumer markets. Annu. Rev. Sociol, 34, 181-209 


\section{Result and Discussion}

\subsection{History Of Human Right In Indonesia}

Every citizen expects that all his rights can be guaranteed in all of his life practices where the state is the guarantor and the enforcement actor. In the enforcement of human rights, three formulations have been given for their implementation, namely respect (to respect), protect (to protect) and fulfill (to fulfill). Before entering the modern phase of regulation and human rights instruments like now, we can see the history of human rights from its inception.

The entire constitutional system and especially for the enforcement of Human Rights does not directly become a structured or detailed part of what we have today. A series of historical movements on human rights can be seen from the development of human rights where people feel suffering, in line with what Lord Acton said "power tends to corrupt, absolute power corrupts absolutely" were in the past many human rights violations occurred. Starting in the 13th century England, King John Lackland (11991216) there was a conflict over arbitrariness carried out by the ruling king who gave rise to the Great Charter of the Magna Carta. In France, in 1789 a French Revolution took place which then presented the Declaration of Human Rights and Citizens ( $\mathrm{La}$ Déclaration des droits de l'Homme et du Citoyen) in recognition of individual rights and human collective rights. In addition to that, the occurrence of World War I (1914) and II (1939) overpower struggles was a severe blow to the consequences and also the suffering caused. Various upheavals and resistance to human rights violations later inspired the birth of documents which were part of the guarantee of human rights. In 1848 internationally the countries jointly agreed on the protection of human rights through the Universal Declaration of Human Rights (UDHR) which became a parameter for its members to implement human rights enforcement in their respective countries.

Indonesia itself as one of the countries that are active in ratifying various international regulations also participates in pouring out the protection of human rights and is involved as a state bound therein.

As a concrete example of the enforcement of human rights in Indonesia, it can be seen in human rights arrangements that form the basis of human freedom (and as citizens' rights) which are regulated in the highest law, namely the 1945 Constitution. Indonesia includes law enforcement, the establishment of a National Human Rights Commission, the establishment of a human rights court, enforcement through human rights promotion and advocacy. The overall efforts made by the Indonesian government are part of the framework for upholding human rights for every Indonesian citizen.

\subsection{State and Enforcement of Human Right}

In the history of human rights development, shows that the emergence of the concept of human rights is inseparable from the reaction to absolute power which ultimately led to the emergence of a constitutional system and the concept of the rule of law, both rechtstaat and rule of law. As stated by Louis XIV with the expression L etat'est Moi or country is me. 
Based on the chronology and facts of history in the past, it can be seen that absolute power and power struggles to war were the classic reasons for the early emergence of movements over human rights enforcement.

A series of international human rights treaties and other instruments adopted since 1945 have conferred legal form on inherent human rights and developed the body of international human rights. ${ }^{2}$

Countries are aware of the losses that exist and then compromise and agree to collaborate and collaborate to reach a prosperous and established country. One of the elements obtained to reach a prosperous country is that the state must make an internal mechanism to regulate voluntary citizens and also protect them directly and indirectly.

This bridge between the state and citizens is then known as the concept of the rule of law where the state becomes the protector and enforcer of the law and especially specifically for human rights.

The following are excerpts from the United Nation regarding the relationship between human rights and the rule of law: ${ }^{3}$

The rule of law has played an integral part in anchoring economic, social and cultural rights in national constitutions, laws and regulations. Where such rights are justiciable or their legal protection is otherwise ensured, the rule of law provides the means of redress when those rights are not upheld or public resources are misused.

That as a legal state, the state plays a role in directing the fulfillment of economic, social and cultural rights into national constitutions, laws and regulations. When these rights are justified or legal protection is ensured, and aim to provide a means of compensation when those rights are misused. Furthermore, the Secretary-General of the United Nation states:

...the rule of law requires that legal processes, institutions and substantive norms are consistent with human rights, including the core principles of equality under the law, accountability before the law and fairness in the protection and vindication of rights...

It is stated that legal rules require legal processes, institutions and substantive norms that are consistent with human rights, including the core principles of equality before the law, accountability before law and justice in the protection and enforcement of rights.

It has been mentioned above that the main elements of human rights enforcement consist of: to respect, to protect and to fulfill, then automatically as a legal state based on the rule of law human rights enforcement mechanism will lead to the above three elements.

The composition is the flow of the mechanism to ensure the functioning of the human rights mechanism itself.

\footnotetext{
2 United Nations Human Right: Office of the High Commisioner. International Human Rights Law. Retrieved From https://www.ohchr.org/en/professionalinterest/pages/internationallaw.aspx

3 Ibid.
} 
"The system of law [must be] sincerely and not unreasonably believed to be guided by a common good conception of justice. It takes into account people's essential interests and imposes moral duties and obligations on all members of society." 4

The United Nations Human Rights states that: ${ }^{5}$

Most States have also adopted constitutions and other laws which formally protect basic human rights. While international treaties and customary law form the backbone of international human rights law other instruments, such as declarations, guidelines, and principles adopted at the international level contribute to its understanding, implementation and development. Respect for human rights requires the establishment of the rule of law at the national and international levels.

Guarantee on human rights enforcement is not only a series of commitments made by the state when meeting in international forums, but the most important thing is how to adapt the constitution and other laws that formally protect human rights in their respective countries. Respect for human rights requires the enforcement of the rule of law at international and national levels.

The concrete mechanism of human rights enforcement (expected to reach the smallest level of society) carried out by Indonesia through the establishment of a structured program to measure the effectiveness of human rights enforcement was made a human rights mechanism, namely Indonesia National Human Rights Action Plan (hereinafter abbreviated as RANHAM), Indonesia, strategies, and focus on priority activities of the Indonesian national human rights action plan and are used as a reference for ministries, institutions, and regional governments in implementing respect, protection, fulfillment, enforcement and promotion of human rights in Indonesia.

To continue the human rights program collaboration is needed and also the continuity of implementation at the regional level as the smallest scale of society. Indonesia itself saw this position and then made improvements since 2004 Indonesia which implemented the Regional Autonomy system (through Law Number 32 of 2004 concerning Regional Government (State Gazette of the Republic of Indonesia of 2004 Number 125, Supplement to the State Gazette of the Republic of Indonesia Number 4437), then automatically the provincial and district / city governments have the same role as the central government in fulfilling and preventing human rights violations in the community.

Regional Government (Pemda or Local Government (LG)) as stated in Article 1 number 1 of Law Number 23 Year 2014 concerning Regional Government (Regional Government Law), is the administration of government affairs by regional governments and people's representatives according to the principle of autonomy and co-administration with the principle of autonomy as wide as the extent of the system and principles of the Unitary State of the Republic of Indonesia as referred to in the 1945 Constitution. Whereas in Article 1 point 2, it is explained that the Regional Government is the regional head as an element of Regional Government

4 John Rawls, (1999). The Law of Peoples in Samuel Freeman, ed., Collected Papers Cambridge: Harvard University Press, p. 529.

${ }^{5}$ United Nations Human Right: Office of the High Commisioner, International Human Rights Law, Ibid. 
administrators who lead the implementation of government affairs under the authority of autonomous regions. Based on this, it guarantees a basis for the local government in acting to protect human rights in Indonesia where the regional government is the spearhead of child protection in the regions and government administrators who handle the protection of human rights. It is hoped that collaboration from the central and regional governments will strengthen the guarantee of human rights enforcement.

By looking at the contents of the human rights treaties that have been ratified, the Regional Government will be able to make studies and strategies to achieve the objectives of its human rights form. In fact, in practice, it was found that Pemda had a high level of attention in fulfilling human rights by establishing a Human Rights Commission in their area: ${ }^{6}$

The International NGO Forum on Indonesian Development (INFID) appreciates the steps of the Wonosobo District Government that formed the Regional Human Rights Commission. This can inspire and stimulate other regions to ground and implement human rights principles in their area.

It is expected that with the Regional Autonomy mechanism, the responsibility of the state, especially the government, in the protection, promotion, enforcement, and fulfillment of human rights. Also, it was emphasized that to uphold and protect human rights following the principles of a democratic legal state, the implementation of human rights is guaranteed, regulated and outlined in its implementation through state instruments and collaboration with other parties within the human rights corridor.

\subsection{Cultures and Multiculturalism of Buton Communities}

Buton Regency is one of the prime level government in Southeast Sulawesi Province, Indonesia. Buton Regency is located on Buton Island which is the largest island outside the main island of the Sulawesi Islands, which makes it the 130th largest island in the world. The capital of Buton Regency is located in Pasarwajo. The regency has an area of 2,488.71 km2 (before the expansion of 6,463 km2) and in 2004 it had a population of 265,724 people (before the division of 533,931 people). Buton Regency is well-known as an asphalt producer.

Buton Regency or also be mentioned as the Kingdom of the Buton Sultanate is also the only region/kingdom in Indonesia that was never colonized by invaders who came to Indonesia (even before Indonesia had a constitution in 1948). The Kingdom of the Sultanate of Buton had implemented a constitution compiled by the sixth King named Dayanu Ikhsanuddin (the constitution is called the Seven Dignity: Martabat Tujuh). Also, the Kingdom of the Sultanate of Buton has started the implementation system of power distribution and became like a modern legal state system earlier then Indonesian structure after independence. ${ }^{7}$

\footnotetext{
6 Nindhitya Nurmalitasari. (2018). INFID Apresiasi Pembentukan Komisi HAM Daerah Pertama di Indonesia. International NGO Forum on Indonesian Development. Retrieved From https://www.infid.org/infid-apresiasi-komisi-ham-daerah-pertama-indonesia/ 7 Wikipedia. Retrieved From https://id.m.wikipedia.org/wiki/Kabupaten_Buton
} 
Anthropologically, the Buton community is a partnership of various sub-tribes that are relatively different, both in terms of physical characteristics (race) and culture. ${ }^{8}$

De Jong 9 in 1982 classified it into five major groups, namely: (i) Buton people who inhabit Buton Island, (ii) Muna people who inhabit Muna Island, (iii) Kobaena people who inhabit Kobaena Island, (iv) Pulo people who inhabit the cluster Tukang Besi Islands, and (v) Moronene people who inhabit parts of the southeastern peninsula of Sulawesi Island. De Jong's classification seems to simplify reality. Because, if traced further people who inhabit Buton Island are quite heterogeneous. Two examples that can be put forward are the Kulisusu people who inhabit the North Buton region and the Cia-Cia people who inhabit the South Buton area. ${ }^{10}$

The same is true for the people who inhabit several other islands that have been in the territory of the Buton Sultanate. De Jong's classification also does not include Bajo people who inhabit coastal areas and islands that were once within the territory of the Buton Sultanate. Their existence as a sea tribe and their role in the sultanate have been widely described through several results of research on Buton. In 1878, the category of the Buton community which was an alliance of various sub-tribes amounted to \pm 100,000 people, and in 1937 it grew to 309,924 people. ${ }^{11}$

The diversity of physical characteristics (races) is also enriched with a variety of languages and customs. From the summary of the various research results obtained information about language, language groups and dialects that are recognized spoken by the Buton community since the era of the sultanate to date, including: Wolio, CiaCia, Kamaru, Lasalimu, Wasuamba, Kulisusu, Kambowa, Kumbewaha, Gonda , Todhanga, Wasilomata, Pahcana (Wuna), Lowu-Lowu, Langkomu, Moronene, Rahantiri, Wanci-Kapota, Kaledupa, Tomia, Binongko, Siompu-Kadatua, and Wawonii. ${ }^{12}$ Also, in 1998, a scientist named Liebner identified about 30 languages and \pm 100 dialects used by the community in the former Buton Sultanate. In the research of maritime languages also obtained information about mapping maritime languages in Buton including Wolio, Binongko, Tomia, Cia-Cia, and Muna-Siompu languages. One language that is no longer well known today is the Tobe-Tobe language. Because so many languages are used by various tribes, making the population of Buton, whose population is relatively small, speaks many languages. One thing that should be appreciated, the issue of language diversity, as one of the multicultural realities in Buton, does not necessarily make people lose contact with each other, because the Wolio language, commonly called Buton language, is their unifying language as a nation since the early development of Buton civilization. This language is a medium for integrating the Buton Sultanate region that extends almost to the area of Southeast

\footnotetext{
${ }^{8}$ Sumbangan Badja. (2012). The Sleeping Giant Buton Raya; Isyarat Ilmiah Menguak Tabir Tujuh. Makasar: Puslitbang Witaris Unhas, p. 15.

${ }^{9}$ Tasrifin Tahara. (2014). Melawan stereotip: etnografi, reproduksi identitas, dan dinamika masyarakat Katobengke, Buton yang terabaikan. Jakarta: Kepustakaan Populer Gramedia. p. 31.

${ }^{10} \mathrm{Ibid}$.

${ }^{11}$ Pim Schoorl. (2003). Masyarakat, Sejarah, dan Budaya Buton. Jakarta: Penerbit JambatanPerwakilan Kitlv, p. 23

12 Ibid, p. 21.
} 
Sulawesi today: on the north bordering the territory of the Kingdom of Luwu, in the south to the Flores Sea, in the east to the Banda Sea, and in the west to the Bone Strait. ${ }^{13}$

In this cultural territory, the multicultural Buton mosaic manifests itself as a colorful dots, forming a social habitat, which on the one hand provides a place for the maintenance of local identity and the particular beliefs of each sub-tribe, and on the other hand, gives space for the process of realizing Buton integration. The diversity of the physical characteristics of a society, language and culture, in general, is a scientific signal that the Buton community is a multicultural society.

The multicultural condition was a real situation that influences the founders of the Kingdom of Buton viewpoint in managing multicultural nation-states. The difference and socio-cultural diversity as the fundamental reality of the people of Buton are not used as a basis for building barriers in rigid separations but become a basis for them to build a life together based on the principle of co-existence. ${ }^{14}$

The principle of co-existence in the structure of the Buton community is multistructural manifest through the willingness of each social group to respect and respect other cultures. This principle was shown by mia patamiana (literally: four main characters) which included Sipanjonga, Sijawangkati, Simalui, and Sitamanajo when pioneering a social alliance which later became the forerunner of the Kingdom of Buton. ${ }^{15}$ The fragment of this story suggests that the group led by Sipanjonga had different origins and different cultures from the group led by Simalui. They agreed to form a social alliance based on mutual respect even though each of them lived based on their customs. It is the same interests and ideals that unite them into one social alliance bond. In modern political language, their agreement can be referred to as a social contract. ${ }^{16}$ The formation of the mia patamiana social alliance then had implications for the transformation of the sub-tribes in Buton which had originally lived separately, autonomously and the independent, into a single alliance which

${ }^{13}$ La Ode Abdul Munafi, PhD Dissertation: "Etnografi Kaomu; Strategi Bertahan Kelompok Bangsawan dalam Struktur Masyarakat Buton", Universitas Hasanuddin, 2016, P. 51.

${ }^{14}$ La Ode Abdul Munafi, PhD Dissertation: "Etnografi Kaomu; Strategi Bertahan Kelompok Bangsawan dalam Struktur Masyarakat Buton", Ibid.

${ }^{15}$ Most analysts said that the mia patamiana as the founding fathers of the Buton Kingdom were the four leaders of immigrants who came from Melayu-Johor. This is the historical construction which has been guided by Buton historiography about mia patamiana. However, there are also other opinions, such as in the thesis proposed by Maula and friends in 2011 which stated that what was meant as a leader of immigrants from Malay-Johor from the four main figures (mia patamiana) was Sipanjonga and Sijawangkati only, while Simalui and Sitamanajo is a local community leader in Buton. In Hikayat Negeri Buton, the figure of Sipanjonga is told and who is the figure of Simalui As the leader of a group of immigrants, Sipanjonga was described as a generous king who later became a sea rider to pursue his dream of building a new kingdom in the land of the rising sun, while Simalui along with his people was described as an indigenous farmer who moved from one place to another in Buton. Over time, the two groups then met in Buton and agreed to build a social partnership. The State Story of Buton recounts this incident: "then they agree (Sipanjonga and Simalui) to gather like the customs of a country, but the laws of each of the two peoples". See Abdul Mulku Zahari, Sejarah dan Adat fiy Darul Butuny, Depdikbud, Jakarta, 1997, p. 37

${ }^{16}$ Muhammad Jadul Maulana., et.al, Kesepakatan Tanah Wolio; Ideologi Kebhinekaan dan Eksistensi Budaya Bahari di Buton, Radjawali Press, Jakarta, 2011, p. 41. 
continued to grow following the joining of several other communities, including TobeTobe. 17

The similarity of interests and ideals, especially in fulfilling shared economic needs is the basis of the social alliance. The mutual relations between them then took place dynamically, because in the social alliance the farmer community had been assembled represented by the Simalui community, the sugar-producing community represented by the Tobe-Tobe community, and the merchant community represented by the Sipanjonga community; immigrants from Melayu-Johor. Buton people the initiative to build alliances and cooperation in order to fulfill common needs while increasing capacity and resources. Over time, their great fellowship eventually needed leaders who could act as protectors of order and social order.

When changes in the natural, social, and political settings are unavoidable, they try to find new equilibrium. As a result, the alliance, which was originally based on socioeconomic relations, which balance each other, experienced a transformation into a political alliance. This is the next round of transformation for Buton sub-tribes towards the integration process when Wa Kaa Kaa, which in mythology is called the daughter of the god Bataraguru, princess fari (fairy), who is also nicknamed mobhetena yi tombula (daughter born through bamboo), was crowned King of Buton, which at the same time marked the beginning of the formation of "state" as an organization of power which accommodated the unity of the sub-tribes. As time went on, the subtribes that integrated themselves into the political alliance grew more and more following the integration of nine other sub-tribes in the Buton Kingdom which continued to be finalized, namely: Kamaru, Batauga, Bombonawulu, Tumadha, Todhanga, Waaleale, Wawoangi, Bhola, and Wolowa, which in the tradition of Buton are commonly called siolipuna (nine countries). ${ }^{18}$

The integration process continued so that in terms of mapping the territory, the Buton Kingdom then included 72 kadie (region land) regions and four bara'a regions in addition to the central region, the Wolio. After the distribution of 72 kadie regions, there were immigrant tribes from the interior of Mandar called the Laporo Tribe. Because this tribe did not get the Kadie area, in order to obtain the domicile area, the Laporo Tribe asked Sara for each tribe that had the Kadie area to be given a small area to live in. it's the Takimpo tribe. ${ }^{19}$

Taking into account the socio-political processes of the establishment of the Buton Kingdom in which various sub-tribes live as described, it can be understood that the unity of the Buton community is not emic-natural but historical-ethical. Naturally, as in terms of physical characteristics (race), culture, and geographical environment, subtribes throughout Buton are not a unity. That they are then more united because of shared historical experience.

The dilemma problem that is often found in the management of diversity is when the nation inevitably has to organize and operate the state in the form of a power

${ }^{17}$ La Ode Abdul Munafi, PhD Dissertation: “Etnografi Kaomu; Strategi Bertahan Kelompok Bangsawan dalam Struktur Masyarakat Buton", Ibid.

${ }^{18}$ La Ode Abdul Munafi, PhD Dissertation: "Etnografi Kaomu; Strategi Bertahan Kelompok Bangsawan dalam Struktur Masyarakat Buton", Ibid.

${ }^{19}$ La Ode Abdul Munafi, PhD Dissertation: "Etnografi Kaomu; Strategi Bertahan Kelompok Bangsawan dalam Struktur Masyarakat Buton", Ibid. 
(structured) organization. According to his intention, the state is intended as a driving force in realizing the ideals of the country systematically and effectively for all its citizens. So, the state is facilitative. ${ }^{20}$

As for understanding the practice of diversity management which is based on the principles of multiculturalism operationalized in state governance in Buton, it is necessary to present several concepts relevant to multiculturalism including democracy, community cultural rights, rule of law, togetherness in diversity, and principles ethics and morals. ${ }^{21}$

Democracy as one unified concept in the conceptual building of multiculturalism, instate governance in Buton, is manifested through the separation of powers between the executive institution led by the sultan and the legislature led by bonto ogena. This practice is intended to provide space for the ongoing check and balance mechanism among state institutions in implementing the government system. This practice is also intended to avoid the ranks of officials involved in corrupt practices and various forms of office misuse that can harm the people.

Democratic practices in state governance also manifest in the process of appointing a sultan through a 'limited election' mechanism, including: recruitment of candidates (own), candidate selection (kambojai), election process (fali), announcement of elected candidates (sokaiana pan), to the inauguration of the chosen sultan (bulilingiana pau). This practice is intended to produce leaders (sultans) who have intellectual, emotional, and spiritual qualities, while avoiding the concentration of power in one circle. Hence, in the tradition of power Buton is not known as a dynasty. Siolimbona, is which can more or less be equated with the position and function of the House of Representatives, where at the present time being the multicultural representation of the Butonese people. This democratic institution has the authority to oversee the administration of the government while accommodating the aspirations of the people (muuna tana) as a formulation of policy.

Furthermore, the practice is a democracy that demonstrated through the giving of autonomy to the regions, both kadie (small autonomous regions) and barata (large autonomous regions). This practice is not only intended to support productivity and efficiency in the implementation of governance in the region, but also as a manifestation of respect for community cultural rights or respect for civil rights, both in political and governmental, social, economic and cultural settings, which are precisely the essence from democracy itself. Through an autonomous government system, each kadie and barata has a system of local governance that is different from one another, according to differences in the way the formation of a kadie or barata, local customs, and special functions relating to the state. Through the implementation of regional government based on autonomy, each kadie and barata has a wide opportunity to develop local productivity and independence according to the potential and distinctiveness of each region. This practice also reflects that the pattern of development approaches in the context of state in Buton does not rest on the principle of monoculturalism but rather multiculturalism.

${ }^{20}$ Daniel T Sparingga. (2003). Multikulturalisme Dan Multi Perspektif di Indonesia. In Surabaya: Forum Rektor Simpul Jawa Timur.

${ }^{21}$ Persudi Suparlan. (2014). Menuju masyarakat Indonesia yang multikultural. Antropologi Indonesia, p. 19. 
The rule of law, which is also an important element in the conceptual building of multiculturalism, in-state governance in Buton, is reflected through the expression of bhone montete yinda posala-sala (no difference for anyone before the law). In practice, even the sultan and the sultanate officials who have been found guilty according to the law will be punished accordingly. The supremacy of the law in the practice of state is realized through (i) pasabu (dismissed, removed, or impeached from his position), (ii) papasi (ostracized from the social environment, or exiled to other regions), (iii) gogoii (dead law through hanging law) ), and (iv) tat as: pulanga (revocation of one's rights and derivatives of certain positions in the government, or revocation of the right to access certain resources in the public space). In the historical record, it was one of the sultans and a number of high-ranking Sultanates who ended his position on the gallows, in Gogoii (sentenced to hang) for the mistakes he made. Indiscriminate law enforcement (bhone montete yinda posala-sala) in the practice of state in Buton, in addition to maintaining the authority of the law itself, while ensuring a sense of justice for all citizens of the multicultural nation.

The practice of democracy, both through the separation of powers between state institutions in the administration of government functions, the appointment of sultans through limited electoral mechanisms, the granting of autonomy to the regions as a reflection of community cultural rights, and fair law enforcement are manifestations of principles the principle of multiculturalism in state governance in Buton. It was Sultan Dayanu Iklrsanuddin, Sultan of Buton IV (1597-1631), becoming a hero in laying down these principles. He has put the practice of democracy in the multicultural governance of the Buton nation long before Monstesqui put forward the idea of trias politico in France in the 18th century. He is an ideologist, the 'father of Buton democracy' who has a brilliant vision of democratic state governance across future barriers, as well as a figure of multiculturalism.

Togetherness indifference, which is also an important concept in developing the paradigm of multiculturalism, in the frame of Butonism, manifests itself through the doctrine of porom yinda saangu-poga yinda kcolota (united united, unrelated separation). This doctrine derives from monotheistic teachings, which are immersed in the oceans of religious spirituality, and then transformed as ethical norms for the multicultural integration of Buton society.

This is the manifestation of the spirit of "Unity in Diversity" in the context of managing the multicultural nation of Buton. This doctrine contains a dual spirit, on the one hand, it does not want to deny the existence of differences and pluralism, not only as a reality that must be accepted but also as capital that must be maintained, even developed. On the other hand, diversity and pluralism must not hinder and defeat the spirit to cooperate, as well as build togetherness, in an effort to realize the shared ideals as a nation. In the order of society, nation and state, social ethics is enforced through four principles (The sara pataanguna), namely: (1) pomae-maeka, (2) popia-para, (3) pomaamaasiaka. (4) the sequence of words that are also included in the preamble of the Seven Dignity Act. These four principles are called sara pataanguna, sara means ethics, law, adat, while pataanguna means four bases or four foundations..$^{22}$

${ }^{22}$ La Ode Abdul Munafi, PhD Dissertation: "Etnografi Kaomu; Strategi Bertahan Kelompok Bangsawan dalam Struktur Masyarakat Buton", Op. Cit. 
The Sara Pataanguna is four bases or four foundations; ethics, law, adat, which are guidelines or orientations on how human beings should behave and behave as members of the multicultural society, not only manifests the principle of co-existence as the basis of multiculturalism, but more than that at the same time manifests the principle of pro-existence, which is indicated, not only by the presence of the quality of peaceful coexistence among various social elements that differ in socio-cultural settings, but also by awareness to participate as part of efforts to solve problems faced by other groups, so that togetherness is guaranteed in diversity, which is not only participatory but also emancipatory.

The idealization of quality of life together based on the principle of sara pataanguna is very much needed by a multicultural nation such as Indonesia, because it allows different groups of socio-cultural backgrounds to have the need to produce integration in addition to local identity and the diverse and particular beliefs that can be maintained.

\subsection{Community Castanization in Buton District}

In the culture and customs of the people of Buton itself since the beginning of the reign of the Kingdom of the Buton Sultanate did not apply the castle system in the community either through regulations or other legal products. However, empirically, the castration system was formed through the results of the interaction of tribes that were considered inferior and other tribes of society.

The Buton Kingdom then included 72 kadie regions and four bara'a regions in addition to the central region, namely Wolio. After the division of 72 kadie territories with each tribe under the rule of the Kingdom of the Buton Sultanate, one immigrant tribe from the inland region of Mandar ${ }^{23}$ entered the territory of the Buton Sultanate. This community group is called the Laporo Tribe. The Laporo tribe initially inhabited Buton Island in remote areas because they did not get the Kadie area. Because their lives in rural areas are difficult to get good water and food sources and very rarely interact with outside communities, making them have unclean and healthy living habits and very low knowledge. Several years later, many of them suffered from dangerous diseases such as skin diseases, cholera, and several other dangerous diseases so that the Royal Government of the Sultanate of Buton took the initiative to order them to descend from inland mountains and live in the domicile of the Royal Buton Sultanate who had supplies healthy water and food sources. But before they lived in 72 Kadie areas, they had to first ask permission from the tribes who owned the Kadie region through Sara Kadiae to be given a small area of their residence. An example of this area is what is now called Laburunci Village, Kombeli Village and Awainulu Village.

Because the Laporo people do not have jobs and tend to beg for the territory of the owner of the Kadie area and have less clean habits, the owners of Kadie offer the people of the Laporo tribe to become unskilled laborers in their gardens, fields or other businesses. or in other words become slaves (batua) of the owners of kadie. ${ }^{24}$ Laporo

${ }^{23}$ La Ode Abdul Munafi. (2016). “Etnografi Kaomu; Strategi Bertahan Kelompok Bangsawan dalam Struktur Masyarakat Buton", PhD Dissertation: Universitas Hasanuddin, p. 10.

${ }^{24}$ Data obtained from interviews with La Makki (Sejarawan Buton) di Kelurahan KambulaMbulana, April 20, 2019, 21:05 PM. 
Tribe people who did not have jobs and sufficient knowledge made them accept the offer fully voluntarily.

The results of the interaction of the Laporo Tribe with the tribe outside the Laporo Tribe as the owner of the cadie have led to the stigma or wrong construction of thinking in the Royal community of the Buton Sultanate which has led to the formation of a system of castration in people's lives.

Within the Laporo tribe, the Laporo tribes in ancient times also accepted their position below. On the contrary, the fact of the Royal Government of the Buton Sultanate only divided the community into 3 groups based on their duties but not in the form of castration. (Indeed, there are groups of Batua people, but members of this community group come from people who committed gross violations of customs). ${ }^{25}$ Therefore, it can be concluded that the castration system of the people in Buton is not a custom or a system formed by the government of the Buton sultanate, but rather formed through the interaction of one of the lower tribes with other tribes in the Buton Islands. ${ }^{26}$

Based on that we conclude the stigma that makes the Laporo people often excluded from the lives of the people, and often get treatments that greatly undermine human dignity. ${ }^{27}$

\subsection{Legal Basis for Establishment of The Human Right District}

The formation of a district of human rights is fundamental because guaranteeing and implementing human rights is one of the demands of reform. Human rights implementation can be carried out at the smallest administrative locus in a country, namely the district. The selection of districts / cities is based on Article 18 of the 1945 Constitution as an implementation of the principle of decentralization. In general, in the laws and regulations in Indonesia there was no order to the regional head to form a human rights district. However, if explored more deeply, we can find a number of regulations that provide opportunities for the establishment of a human rights district.

a) The 1945 Constitution of the Republic of Indonesia

The guarantee of human rights that refers to the establishment of the Regency of Human Rights in the 1945 Constitution of the Republic of Indonesia reflected in Article 28I paragraph (4) reads "Protection, promotion, fulfillment and enforcement of human rights are the responsibility of the state, especially the government. "In addition, Article 18A explains that the government in Indonesia consists of the Central Government and Regional Governments which carry out their duties in accordance with the principle of autonomy and co-administration. In addition, Article 18B explains that the state recognizes and respects special regional administrations and recognizes the existence of

${ }^{25}$ Data obtained from interviews with Drs. Murtaba Muru, M. A. (Chair of the Laporo Tribe Family Harmony) in Lingge-Lingge Village, April 21, 2019, 17:31 AM.

${ }^{26}$ La Ode Abdul Munafi, "Memahami Esensi Sara Pataanguna dalam Undang-Undang Martabat Tujuh Buton", Op. Cit.

${ }^{27}$ Data obtained from interviews with Tasrim, S.Pd., M.Pd. (Buton Academics) in Saragi Village, Pasarwajo District, April 18, 2019 At 09:37 AM. The argument also gets support or has a correlation with the arguments that the author gets from Drs. Amruddin (Head of Pasarwajo Sub-District) at Pasarwajo Sub-District Office, April 182019 at 3:08 PM. 
customary law communities along with the development of Indonesia. In relation to the two Articles, the state is obliged to protect, promote, fulfill and enforce human rights through the regional government by establishing a human rights district.

b) Law Number 39 of 1999 concerning Human Rights

Article 28I The 1945 Constitution of the Republic of Indonesia is in line with Article 8 of Law Number 39 of 1999 concerning Human Rights which states that the protection, respect, enforcement and fulfillment of human rights are the responsibility of the state, especially the Government. This provision is also in line with Article 71 and Article 72 of Law No. 39/1999, which states that the Government must and is responsible for respecting, protecting, enforcing and promoting human rights as regulated in this Law, other laws and regulations, and the law international human rights, accepted by the Republic of Indonesia. ${ }^{28}$

The obligations and responsibilities include effective implementation steps in the legal, political, economic, social, cultural, defense and security sectors, and other fields.

For Regional Governments, based on their authority as stipulated in the 1945 Constitution, they can implement human rights in the field of law, by establishing Regional Regulations or other regional legal products. On the basis of his own initiative, the Regional Regulation can be in the form of the application of human rights cities in his area.

c) Law Number 23 Year 2014 concerning Regional Government

Law Number 23 Year 2014 concerning Regional Government is the implementation of Article 18 paragraph (7) of the 1945 Constitution. This law reaffirms the implementation of the principle of autonomy and coadministration, as stipulated in the 1945 Constitution. Regional Governments can make human rights the basic framework for implementing regional governance. Thus the human rights city/ district becomes relevant for human right protection in society. Based on Law Number 23 Year 2014, the obligations of regional governments are:

1) Protecting the community, maintaining national unity, unity and harmony, and the integrity of the Unitary State of the Republic of Indonesia.

2) Improve the quality of life of the community

3) Develop democratic life

4) Realizing justice and equity

5) Improve basic education services

6) Providing health care facilities

7) Providing decent social facilities and public facilities

8) Develop a social security system

9) Develop regional planning and spatial planning

10) Develop productive resources in the area

11) Preserve the environment

${ }^{28}$ Law Number 39 of 1999 concerning human rights. 
12) Managing population administration

13) Preserve socio-cultural values

14) Establish and implement laws and regulations in accordance with their authority.

15) Other obligations stipulated in legislation.

d) Presidential Regulation Number 75 of 2015 concerning National Action Plan for Human Rights.

The Gwangju Declaration on the City of Human Rights, states that districts / cities of human rights are local communities as well as socio-political processes in local contexts, where human rights are important players as fundamental values and guiding principles. In other words, human rights cities want the application of human rights norms and standards in local communities, as well as socio-political processes in the local context. This is in line with Presidential Regulation Number 75 of 2015 concerning RANHAM. Article 3 of Presidential Regulation 75 of 2015 states that Ministers, heads of institutions, governors, and Regents / Mayors are responsible for implementing RANHAM, in accordance with their respective authorities, based on the provisions of legislation and regulations. ${ }^{29}$

In the appendix of Presidential Regulation Number 75 of 2015, as a unit of the Presidential Regulation, it is stated that the RANHAM General Objective is to increase respect, protection, fulfillment, and promotion of human rights for all levels of Indonesian society, especially the government, taking into account religious, moral customs, culture, security, public order, and the interests of the Indonesian people based on Pancasila and the 1945 Constitution of the Republic of Indonesia. To achieve the RANHAM target for 2015-2019, Presidential Regulation 75 of 2015 stipulates the 6th RANHAM implementation strategies, namely:

1) Strengthening RANHAM implementing institutions

2) Preparation of ratification and preparation of material for the report on the implementation of international human rights instruments

3) Preparation of regulations, harmonization of draft legislation and evaluation of legislation from a human rights perspective

4) Education and public awareness about human rights; 11 Application of human rights norms and standards

5) Community communication services. Thus, city human rights are in line with the 2015-2019 RANHAM fifth strategy, namely: the application of human rights norms and standards. Especially for Regional Governments.

\subsection{Establishment of The Buton as a District of Human Right}

\section{A. Buton Regency and its tribe}

The Laporo tribe as one of the sub-tribes in Buton with a historical record that accepted their position functionally in the community grouping, which became unskilled

${ }^{29}$ Ibid. 
laborers in gardens, rice fields, or other businesses belonging to other tribes, creating a status that they were workers and then it became a kind of "mention" of them as slaves (Batua) of the landowners (Kadie owner). Laporo tribesmen who did not have jobs and sufficient knowledge made them accept the offer of work in full voluntary terms (by looking at existing historical records). The results of the interaction of the Laporo Tribe with the tribe outside the Laporo tribe as the owner of the Kadie This is what gave rise to the wrong stigma on the Laporo tribe and led to the formation of the castle system in the lives of the people. Within the Laporo tribe, the Laporo tribe considered themselves to be born slaves. In fact, not a few of them thought that the Buton kingdom government had formed the castration system in the community and made the Laporo tribe a slave group. ${ }^{30}$

It is this stigma that makes the Laporo people often ostracized in the lives of the people, and often get treatments that greatly undermine human dignity. Therefore, the application of the principles of human rights and the establishment of a Human Rights District need to be carried out in Buton Regency as a form of escorting the Human Rights of each individual.

\section{B. Human Rights District}

The district government also has obligations and duties to promote and protect human rights in Indonesia. Not only is the duty and obligation of the central government, the National Human Rights Commission and civil society groups. Human Rights District is "Cities and districts that seek to implement city policies and institutions to respect and protect human rights". ${ }^{31}$ In accordance with the mandate of the International Declaration on Human Rights, the 1945 Constitution and and the Indonesian Human Rights Law. City of HAM is nothing but the city "for all". Cities that prioritize and implement policies to become decent cities / districts, free of intolerance discrimination, and become cities that protect the rights of children, women and the elderly. 32

Human rights districts will strengthen themselves with various institutions to be better able to implement, and monitor the implementation and realization of human rights in their regions. The HAM District will design and implement an integrated action plan in the Regional / City and District Government Work Plans (RKP-D). This includes the realization of local human rights regulations, human rights offices and budget allocations needed. ${ }^{33}$

\section{Benefits of the Human Right District}

1. Strengthening government capacity

Public service is part of respecting and protecting human rights. Human rights districts will directly and indirectly encourage and encourage strengthening public services, sensitivity to voices and the aspirations of

\footnotetext{
${ }^{30}$ Data obtained from interviews with Drs. Murtaba Muru, M. A. (Chair of the Laporo Tribe Family Harmony) in Lingge-Lingge Village, April 21, 2019, 17:31 AM.

${ }^{31}$ Antonio Pradjasto H. (2015). Panduan Kabupaten dan Kota Ramah Hak Asasi Manusiajakarta Selatan: Infid, p. 9

32 Ibid.

${ }^{33}$ Ibid. p.15
} 
citizens. Also encouraging the government to give priority to the layers of society that have been marginalized.

2. Strengthening the Realization of Human Rights for All Layers of Society

Human Rights District encourages improvements in policies and programs of city and district governments in an effort to improve the quality of life and human rights of groups that have been vulnerable and marginalized, such as: disabled communities, the elderly and children. Human rights districts also encourage improvements in areas that have not received government services such as sanitation and clean water, education services and health services. ${ }^{34}$

3. Strengthening the "Government for All" that is Imparential and Nondiscriminatory

The Regency of HAM requires the government to protect all groups including minorities in exercising their rights to worship. In addition, it obliges the government to take an impartial stance and at the same time protect all without exception. That way, the HAM District also refused and prohibited local governments from discriminating, for any reason.

4. Helping Local Government to be an Open and Responsive Government

One indicator of the Regency of Human Rights is to encourage an open, participatory government and be responsive to public voices and complaints. That is, a government that has the characteristics of being willing and able to listen to the voices of citizens.

5. Helping and Accelerating Communities that are harmonious, tolerant and peaceful

District Human Rights will help local governments be more capable and strong in maintaining and caring for Indonesia's diversity. The Regency of Human Rights strongly supports the way local governments reach harmonious communities, work together and strengthen social capital.

\section{Urgency for the Formation of Human Rights Districts}

In the implementation of human rights (HAM), the condition has progressed from time to time even though there have been some disturbing cases. The steps to ratify UN human rights to enforce the law No. 39 of 1999 became a force to encourage the realization of better practices in the daily lives of people and countries, while preventing the practices of human rights violations. In connection with this, it is necessary to translate the big idea of human rights from the state level to the local domain position by designing a concept of human rights city. Citizens are placed in the most important position in each development process.

One indicator is the city that is friendly to pedestrians and people with disabilities. This concerns the condition of road, sidewalk, to urban planning infrastructure that sits in the interests of all groups, including people with disabilities. In addition, children and seniors will receive hospitality in access with the availability of green open spaces and adequate playgrounds. The safety aspect is conducive to a comfortable life size. So,

${ }^{34}$ Ibid. 
every citizen is free to move without having to be overshadowed by fears and worries over, for example, criminal acts.

Another indicator as a condition of the human rights city is the improvement of government services. Thus, the practice of public services can be more effective, transparent and accountable. Public awareness to live together in ethnic differences, religion including the school of thought or understanding in racial religion, so that differences in skin color and language were encouraged. Diversity is not a problem, but on the contrary, it will be a blessing. Citizens or individuals are guarded against threats of human rights violations. Both what the state does for its citizens and among the residents of the district / city.

E. Criteria for District Care of Human Rights based on Minister of Law and Human Rights Regulation of the Republic of Indonesia Number 25 of 2013 concerning Amendments to Regulation of the Minister of Law and Human Rights Number 11 of 2013 Concerning Criteria for Districts / Cities Caring for Human Rights.

1. Right to Life (Number of maternal deaths, ${ }^{35}$ Number of infant deaths, 36 Vegetation cover in a protected area $^{37}$

2. Right to Develop personal life (Percentage of children aged 7-12 years who have not received primary school education, 38 Percentage of children aged 13-15 years who have not received junior high school education, 39 Percentage of children with special needs who receive education, ${ }^{40}$ Percentage of illiterates. ${ }^{41}$

3. Right to Welfare (Provision of clean water for the needs of the population, Percentage of low income families who do not have a home, ${ }^{42}$ Percentage of unfit

35 The number of maternal deaths is the number of women who die from a cause of death associated with impaired pregnancy or treatment (excluding accident or incidental cases) during pregnancy, childbirth and during the puerperium (42 days after delivery) regardless of gestational length per 100,000 live births.

${ }^{36}$ The number of infant deaths is the number of babies who die before reaching the age of 1 year Infant Mortality Rate per 1000 live births in the same year.

${ }^{37}$ Vegetation cover is land cover in the form of primary forest, secondary forest, plantations, mixed gardens, and bushes.

38 The percentage of children aged 7-12 years who have not received primary school education is a comparison between children aged 7-12 years who have not received primary school education with all children aged 7-12 years.

39 The percentage of children aged 13-15 years who have not received junior high school education is a comparison between children aged 13-15 years who have not received junior high school education with all children aged 13-15 years.

40 The percentage of children with special needs who receive education is a comparison between children with special needs who get education with all children with special needs Children with Special Needs (ABK) are children with special characteristics that are different from children in general without always showing mental, emotional or physical disabilities. Included in the ABK include Blind, Deaf, Impotent, Tunadaksa, Tunal, Autistic, Downsyndrome, Mental setbacks.

${ }^{41}$ The percentage of illiterates is the comparison between the number of illiterates and the total population. Persons with illiteracy are people who do not have the inability to read and write.

${ }^{42}$ Low-income families are families that have limited purchasing power so they need to get government support to get a house. The percentage of low-income families who do not own a home is a comparison between the number of low-income families who do not have a home and the total number of low-income families. 
for housing, ${ }^{43}$ Percentage of unemployment, ${ }^{44}$ Percentage of reduction in the number of street children from the previous year to the current year, 45 Percentage of malnourished children under five, ${ }^{46}$ Percentage of families that do not have access to the electricity network). ${ }^{47}$

4. Right to Security (Number of anarchist demonstrations) $)^{48}$

5. Women's Rights (Percentage of women's representation in regional government positions ${ }^{49}$ Percentage of violence against women). ${ }^{50}$

\section{F. District Human Rights Principles}

Following are the principles that can be used as guidelines in realizing the City of Human Rights. This principle was adopted from several Declarations of the City of Human Rights and contextualized with Indonesia. These principles include:

1. Principles of Regency Rights

The Regency is a shared space for all residents who live and live in the region. Therefore, every citizen has the right to conditions that respect political, civil, economic, social and cultural rights, as well as ecological developments. Local governments through facilities and infrastructures as well as available resources continue to encourage and increase respect for the dignity and quality of life for their citizens and strive for solidarity as citizens.

${ }^{43}$ The percentage of the number of uninhabitable houses is a comparison between the number of uninhabitable houses and the total number of houses available. Non-residential houses are houses that do not meet the following criteria:

a) Building safety requirements include:

1) bottom structure / foundation;

2) middle structure / column and balak (Beam);

3) upper structure.

b) Ensuring health includes lighting, airing and sanitation, and

c) Meet the minimum area of $7.2 \mathrm{~m} 2 /$ person up to $12 \mathrm{~m} 2 /$ person.

${ }^{44}$ The unemployment percentage is the ratio between the amount of unemployment and the total workforce. Unemployment is people who enter the workforce (15-64 years) who are looking for work and have not yet obtained it. People who are categorized as not looking for work include: housewives, middle school, high school students, university students and others who for some reason do not need work.

${ }^{45}$ Street children are children who are forced to work on the streets and at red light intersections, stations, markets and other public spaces.

${ }^{46}$ The percentage of malnourished children under five is the comparison between the number of malnourished children and the number of children under five.

47 The percentage of families that do not have access to the electricity network is a comparison between the number of families that do not have access to the electricity network and the total number of families.

48 The number of anarchist demonstrations is the number of demonstrations that caused damage to facilities and infrastructure, victims died and seriously injured.

49 The percentage of women's representation in positions in regional government is a comparison between the number of women who hold positions in regional government.

50 The percentage of violence against women is a comparison between the number of women who experience violence with the number of all women. Violence against women includes: actions or actions against women which result in causing physical, sexual or psychological misery or suffering for women. 
The district government of HAM guarantees the rights of every occupant in it; the rights to enjoy a decent life with full access to a healthy environment, and access to basic public services. Including housing / housing, and mobility that is affordable and acceptable.

2. Principles of Respect for Human Rights

Human rights districts are local governments that want a human rights framework as a driver for development for their citizens. Recognition and respect for human rights are the basic principles that must be accepted, and implemented to create a dignified and prosperous society, as has been recognized in the 1945 Constitution and other national legislation.

3. The principle of non-discrimination

Human rights districts are governments that carry out non-discrimination policies. It does not distinguish treatment from citizens based on religion, ethnicity, race, ethnicity, group, class, social status, economic status, gender, language, and political beliefs. Human rights districts must not limit, harass, direct or indirect exclusion that results in the reduction, deviation, or elimination of the recognition, implementation or use of basic rights and freedoms in life, both individually and collectively, in the fields of politics, economics, law, social, culture and other aspects of life. This includes providing access to basic services to all without differentiation and affirmative action to reduce injustice, and strengthen vulnerable and marginalized groups.

4. Principles of Gender Equality

Human Rights District seeks to create and realize men, women, and other gender identities, get equal opportunities and rights as humans. In order for them to be able to play a role and participate in political, economic, social, legal, cultural and educational activities, as well as similarities in enjoying the results of the development carried out. Practical and strategic steps to create conditions for gender equality must be carried out through the integration of a gender perspective in every policy, both in the form of legal products and operational technical policies to realize districts that respect and respect and protect women and other gender identities.

5. Principles of Regional Autonomy

The Regency is part of the Unitary State of the Republic of Indonesia which is given the authority to manage its own household based on the principle of regional autonomy. District Human Rights are held in the framework of carrying out the functions of regional government as stipulated in Law Number 23 Year 2014 concerning Regional Government and other laws and regulations to achieve a just and prosperous society.

6. Principle of Solidarity

Human Rights District is a regional government that makes human rights a fundamental value and guiding principle for the community and the local government itself. Human rights districts want the involvement of all stakeholders (government, community, businessmen, etc.) who work 
together to improve the quality of life for all citizens in a spirit of solidarity and partnership. Human rights districts must also promote social cohesion and cultural diversity based on mutual respect between communities that have different backgrounds, be they race, religion, language, ethnicity, and cultural background.

7. Principles of Participation, Openness and Accountability

Human rights districts want citizen participation in every policy taken by the regional government. Human rights districts must provide effective and accountable mechanisms to ensure the fulfillment of the right to public information, communication, and participation in decision making, implementation and monitoring.

8. Principles of Alignment towards Vulnerable Groups, and Marginals

Human Rights District is a district / city for all who respect human dignity. Human rights districts guarantee a minimum standard of living to enjoy a decent life, the rights of persons with disabilities, children, young people, the elderly, and other vulnerable groups.

9. Principles of Freedom of Expression

The Human Rights District is a district that was built jointly with all stakeholders. The Regency of Human Rights respects and respects and protects the rights of citizens to freely express and express in various forms without any intervention or pressure from any party, as long as this does not conflict with the prevailing laws and regulations. Human rights districts guarantee the freedom of their citizens to express their thoughts and opinions and opportunities to communicate.

10. Principle of Welfare

Human rights districts aim to create community welfare by making human rights a basic framework and values so that people are free from fear and impoverishment. Human rights districts make every effort to ensure the actualization of their citizens, through work and rights for workers; guarantee a healthy life and free from disease; guarantee the availability of residential and pleasant residential environments; guarantee the right to education that can be accessed by all parties; and guarantee the right to a healthy environment. Human Rights District is a city that guarantees its citizens access to food, clean water, housing, education, health services, and jobs that adequately fulfill their daily needs.

11. Principles of Protection of Fundamental Rights

Human Rights District is a district that requires the implementation of human rights based on international principles, the 1945 Constitution and other laws and regulations. Human Rights District must recognize the right to life, the right not to be tortured, the right to freedom of thought and conscience, religious rights, the right not to be enslaved, the right to be recognized as a person before the law, and the right to be prosecuted on retroactive law, are human rights that cannot be reduced under any circumstances. 
12. Principles of Human Rights Mainstreaming

Human rights districts apply a rights-based approach to government policy-making and bureaucracy including planning, formulating, implementing and monitoring and evaluating these policies.

\section{G. Stages and Processes Towards Human Rights Districts}

This process is a framework that guides how to develop District Human Rights (HAM) in a particular district / city community. Although human rights are universal, each district / city has different challenges and problems in making human rights fundamental values in the behavior of all citizens in it and district public policy.

Each district is not always in the same situation, both in terms of human rights situations and in terms of stakeholder strength. Therefore standardization of this process can be used flexibly. ${ }^{51}$

The first step in forming a Human Rights District is to develop a strategy to address the complexity of the problem. This strategy should be based on an initial assessment (assasment) to see the complexity of the district's problems. With the information obtained in the initial mapping, and adhering to the principles of the district government as a Human Rights District, as well as civil society carrying out the next steps.

This strategy should pay attention to the involvement of stakeholders, especially those who are vulnerable, marginalized (or potentially marginalized) and excluded in all stages of the development cycle on a committee. Overall, there are four stages of implementation towards the City / District Human Rights, namely:

\section{Stages and Processes (S\&P) Towards Human Rights Districts ${ }^{52}-P l a n n i n g$}

This stage consists of 3 elements, namely:

a) Ensuring Commitments from Stakeholders

The commitment of the regional head is very important in developing the HAM District. This commitment should be manifested in a public statement in the form of a declaration so that the public can participate in developing the HAM District. Other forms of commitment can be in the form of public law products such as regional head decrees (SK) to form a Committee / Steering Committee for the Formation of Human Rights Districts. This decree contains the responsibilities and working period of the steering committee / committee.

b) Formation of the Steering Committee / Committee

Building a human rights-friendly district requires the participation of all elements engaged in all issues related to the quality of life in the Regency. Therefore, the initiator who is committed to developing Human Rights District can begin by identifying the stakeholders, namely civil society organizations, community communities, government institutions, and parliament.

\footnotetext{
51 Antonio Pradjasto H, et.al., p. 41.

52 Then Abbreviated (S\&P)-Human Rights Districts)
} 
c) Initial Assessment

The steering committee conducts an initial assessment of the human rights conditions in the district. This initial assessment aims to:

1) Mapping the conditions and gaps between universal human rights standards and everyday conditions / practices.

2) Finding the modalities that have been owned by the stakeholders, namely: district governments, civil society, and other parties to realize district human rights.

3) Reviewing regulations, policies, programs and procedures that limit or potentially limit human rights

\section{S\&P Towards Human Rights Districts-Establishment of a Steering Committee / Committee}

Building human rights-friendly districts requires the participation of all elements that move on all issues related to the quality of life in the Regency. Therefore, the initiator who has a commitment to develop the Human Rights District can start by identifying stakeholders, namely civil society organizations, community members, government institutions, and the DPRD. The involvement of other institutions engaged in the fields of human rights, such as: issues of poverty, social welfare, women, children, the elderly, the right to work, LGBT, disability, the environment, the right to information, past human rights violations, also very important.

Next formed a steering committee / committee consisting of representatives of the groups mentioned above. The steering committee / committee has the function of directing, facilitating and supervising this District Human Rights program. The steering committee / committee can be divided into several working groups, whether based on human rights issues, fields of movement (eg research, counseling / education, receiving complaints, All), or spatial (for example, sub-district or village / village-based).

\section{S\&P Towards Human Rights Districts-Initial Assessment}

The steering committee conducted an initial assessment of the condition of human rights in the district. This initial assessment aims to:

1) Mapping conditions and gaps between universal human rights standards and everyday conditions / practices:

i. Mapping the gap between human rights standards and daily practices. Especially mapping the barriers to enjoyment of human rights experienced by all citizens, including vulnerable groups. This mapping can be used to prioritize human rights policies.

ii. Review regulations, policies, programs and procedures that limit or have the potential to limit the enjoyment of human rights, including: MediumTerm Regional Development Plan Documents, Regional Work Plans, Regional Regulations and procedures for policy formulation and public services. 
2) Finding the modalities that have been possessed by stakeholders, namely: district governments, civil society, and other parties to realize the HAM district.

i. This modality can be in the form of good practice of efforts in respecting, protecting and fulfilling human rights that have been carried out by local governments, civil society and business groups and the media.

ii. Finding district government modalities can be done by mapping social welfare programs or policies or social justice that have been owned by the local government, using the main values of the city of human rights, namely non-discrimination, equality and participation. These programs are usually related to economic and socio-cultural rights such as the fulfillment of the right to health, the right to education, protection of women, protection of children, housing and adequate and other housing.

Seeing the modalities of civil society can be done by identifying initiatives from community groups or community support when a district faces issues of human rights, organizational capacity, network coverage, and institutional performance.

Look at the modalities of business groups by identifying business group programs that have contributed to the appreciation of human rights. Existing modalities can be a starting point for encouraging or developing a culture of human rights in the leadership and bureaucracy of the city / regional government and society in general.

4) Reviewing regulations, policies, programs and procedures that limit or potentially limit the enjoyment of human rights of all citizens, including vulnerable groups (women, the elderly, persons with disabilities, LGBT, race / ethnic minorities, minority religions / beliefs). Included in this section is the City Planning Plan.

\section{S\&P Towards Human Rights Districts-Determining Policy Priorities}

Every city or district has special social conditions and problems. Therefore, local governments can begin to determine the priority of human rights policies that will be carried out. Priority should be based on the most urgent rights issue to be fulfilled. For example, if school dropouts are very large even though the percentage of productive age is also high, then the local government can prioritize the birth of policies that ensure all children in the area receive quality basic education.

Methods for determining policy priorities can be from various sources:

a. Using the results of the initial assessment which is further strengthened by a series of discussions in the working group on the steering committee.

b. Conduct multi-stakeholder consultations.

c. Conduct public consultations to expand the spectrum of citizen participation. Public consultation can be carried out through various channels such as the use of information technology, public activities held by the government (festivals and exhibitions), surveys, community consultation forums, and others. 


\section{S\&P Towards Human Rights Districts-Action Plan}

The Regency Human Rights Action Plan is a comprehensive plan that translates statements of human rights commitments into human rights policies. The steering committee / committee develops special programs for various human rights issues as well as the human rights district standards. The general action plan is as follows:

a. City / Regency Government Areas include:

1) Government Administration

i. Amendments or revoke regulations that violate or potentially hinder the enjoyment of citizens' human rights.

ii. Modify policies and procedures that violate or potentially violate human rights.

iii. Make legal regulations or products that explicitly require local governments to protect and promote human rights.

iv. Disseminate the District Human Rights program to all levels of the local government bureaucracy (SKPD, sub-district apparatus, kelurahan / village apparatus).

v. Codify human rights programs in the form of regional legal products.

vi. Reviewing the City Planning Plan and developing a Town Planning for the City of Human Rights.

vii. Ensure the preparation of human rights based district government budget allocations.

2) Human Resources

i. District governments must ensure human rights training for all government staff. This training also includes apprentices or prospective civil servants in the Koto / Regency government. This training can be done in stages.

ii. Arrange standards of behavior for employees in the bureaucratic environment that ensures that human rights are a guideline in daily behavior.

\section{S\&P Towards Human Rights Districts-Implementation and Institutionalization}

Institutionalization of human rights is at the heart of the sustainability of the HAM District. Institutionalization means that the values of human rights are part of the daily habits of the residents of the regency, both those in government, in civil society and business. This includes the establishment of institutions, the existence of legal rules and the process of continually cultivating human rights values.

The first aspect that can be done is to determine what agency will spearhead the implementation of the HAM District. The agency should have the authority to link citizens with the local government (executive), be able to coordinate the planning and implementation of Action Plans or programs for the realization of Human Rights Districts (such as Bappeda), the agency has a fairly impartial mechanism in monitoring the realization of the HAM District.

The second aspect is the regulation in which the local governments can enact regional regulations and Regent Decree. It reflected the commitment to be a basic human rights in the development of the city / regency, the principles that became the basis of work such as public participation and so on, institutions that would become 'motorbikes' in 
the realization of the HAM District, various main programs for the realization of the HAM District monitoring and evaluation.

The third aspect is the formulation of various programs which are translations of the established action plans. This includes budget allocations and concrete activities with measurable steps.

\section{S\&P Towards Human Rights Districts-Evaluation and Monitoring}

Monitoring and evaluation aim to determine the progress of the program's implementation, identify obstacles, and assess the results of the program. The steering committee makes and establishes a monitoring mechanism, including compiling indicators of achievement of each action plan, with a human rights impact assessment approach. Included in the achievement indicators are the existence of human rights considerations in the formulation of regulations, policies, and performance of government staff.

a. Citizen participation

The ideal process of monitoring and evaluation can be done by anyone. Not only the government and steering committee, but also all levels of the community. Therefore, in the monitoring and evaluation mechanism, it must open up space for community participation in monitoring.

b. Reporting

Reporting can be done on all programs to build a Human Rights District and can also be done specifically on several issues which are the main concern of the local government / steering committee. It is necessary to develop procedures to document the progress of the implementation of the action plan including examples of good practice.

\section{H. Principles in Formulating Buton Regency Human Rights Indicators}

Universality: (1) Protect rights without discrimination for any reason, such as race, gender, age, disability, nationality, religion, economic conditions, and social status (2) Ensure the right to live freely in all regions such as politics, economics, the environment and Culture.

Regionality: (1) Realizing the Attitude of "Mutual fear of violating Human Rights" in the reality of social life, or in the context of Relationship between individuals and between groups that differ in their socio-cultural settings (2) Realizing the attitude of "Protecting each other among humans" as a form of manifestation of the upholding of human nature that is immersed in humans (3) Realizing the attitude "Love each other among fellow humans" by every human being across the barriers of differences in race, ethnicity, culture, class, or religion (4) Realizing the attitude of "Mutual respect among fellow humans" as a manifestation of human duty as a caliph, which is rewarding others, in the form of respect (5) Improve the quality of relationships between citizens in daily life, such as participation, and welfare,

Benefits: (1) Opportunities to carry out useful practices for strengthening, evaluating and monitoring human rights policies (2) Opportunities to compare and evaluate the 
level of implementation of human rights with other districts and countries (3) Indicators can be truly measured (including measuring compliance).

\section{Important Value of Buton Regency HAM Human Rights Indicator:}

(1) Encouraging the implementation of human rights, by placing residents of Buton Regency in important positions. The aim of implementing human rights is primarily to pay attention and realize happiness in the community. (2) Identifying human rights conditions in Buton District. Identify current human rights conditions and prepare information to create human rights enforcement policies. (3) Guidelines for human rights policies. use guidelines and instructions in implementing human rights. Special steps must be taken to improve the conditions for implementing human rights, through identifying conditions, seeking and encouraging the creation of specific policies as expected by the community. (4) Contribute to implementation, Encourage policies that are appropriate for realizing goals, evaluations, and supervision.

\section{J. Action Plan Proses Pembentukan Kabupaten Buton Menjadi Kabupaten HAM}

Tabel.1. Action Plan

\begin{tabular}{|c|c|c|}
\hline \multirow{3}{*}{ Norm } & Charter & $\begin{array}{l}\text { Charter Declaration of Buton } \\
\text { District as Human Rights Care } \\
\text { (Peduli HAM) }\end{array}$ \\
\hline & Local Regulation & $\begin{array}{l}\text { The Process of Formulating and } \\
\text { Establishing the Buton Regency } \\
\text { Human Rights Regulations }\end{array}$ \\
\hline & Others & $\begin{array}{l}\text { Declaration of Buton Regency as a } \\
\text { Human Rights District }\end{array}$ \\
\hline \multirow[b]{2}{*}{ Institution } & $\begin{array}{l}\text { Human Right } \\
\text { Divissions }\end{array}$ & $\begin{array}{l}\text { Establishment of the Human Rights } \\
\text { Division. The divison job is to } \\
\text { formulate human rights policies } \\
\text { and support the Human Rights } \\
\text { Ombudsman and the Local Human } \\
\text { Rights Commission. }\end{array}$ \\
\hline & $\begin{array}{l}\text { Local Human Rights } \\
\text { Commission }\end{array}$ & $\begin{array}{l}\text { Establishment of the Local Human } \\
\text { Rights Commission. to facilitate the } \\
\text { mechanism of citizens to } \\
\text { participate in ensuring the } \\
\text { fulfillment of human rights. Its } \\
\text { members consist of citizens who } \\
\text { have awareness and competence in } \\
\text { terms of human rights. They are } \\
\text { appointed regional heads based on } \\
\text { recommendations from civil } \\
\text { society, the DPRD, or } \\
\text { administrative branches of the city. } \\
\text { Through this commission citizens }\end{array}$ \\
\hline
\end{tabular}




\begin{tabular}{|c|c|c|}
\hline & & $\begin{array}{l}\text { monitor whether the local } \\
\text { government has implemented the } \\
\text { provisions of the Human Rights } \\
\text { District Charter. }\end{array}$ \\
\hline & $\begin{array}{l}\text { Human Rights } \\
\text { Ombudsman }\end{array}$ & $\begin{array}{l}\text { Establishment of the Human Rights } \\
\text { Ombudsman. His job is to recover } \\
\text { from violating human rights. The } \\
\text { role of this institution is to provide } \\
\text { protection and guarantee of human } \\
\text { rights by conducting investigations } \\
\text { on human rights in local } \\
\text { communities and carrying out } \\
\text { victims' recovery. }\end{array}$ \\
\hline \multirow[b]{4}{*}{ Policy } & $\begin{array}{c}\text { National Action Plan } \\
\text { for Human Rights } \\
\text { (RANHAM) }\end{array}$ & $\begin{array}{l}\text { pengumuman Rencana Aksi Dasar } \\
\text { Kabupaten HAM Buton }\end{array}$ \\
\hline & Human Rights Index & $\begin{array}{l}\text { pengumuman Indikator HAM } \\
\text { Kabupaten Buton }\end{array}$ \\
\hline & $\begin{array}{l}\text { Human rights } \\
\text { education for } \\
\text { gorvernment officer }\end{array}$ & $\begin{array}{l}\text { Forming a Local Human Rights } \\
\text { Education Board As a training } \\
\text { provider for } \\
\begin{array}{l}\text { instructors for human rights } \\
\text { education }\end{array}\end{array}$ \\
\hline & Individual Policy & 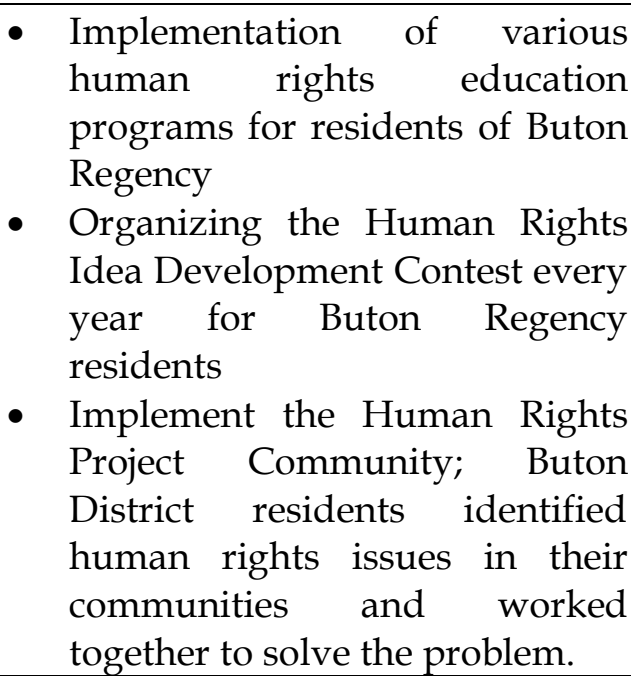 \\
\hline
\end{tabular}

\section{Conclusion}

This paper wants to see whether Indonesia has been able to protect human rights and whether a pluralistic Indonesian society can support the upholding of human rights and specifically prevent discrimination in social life (at the level of regional government especially in the smallest or sub-tribal groups). 
Indonesia has been active in various efforts to guarantee the protection of human rights. This can be seen from a number of legal regulations and policies, instruments up to the judicial system that is devoted to the function of guarding human rights enforcement.

The interesting part of the plurality of Indonesian society is how to unite the implementation of human rights protection if faced with a community that holding the customary law. An example is the Buton indigenous people who have a sub-tribe, namely the Laporo tribe.

Since ancient times the Buton kingdom has implemented human rights values in various fields of community life, this is evidenced by the lack of a dynastic system in government, meaning that if a father becomes king, his son should not become king again because of equal position and opportunity for the entire community in the government, the enactment of the Dignity Act 7 as the legal basis for implementing human rights values. The cassation system in the Buton community is not a custom or a system formed by the government of the Buton Kingdom but is formed through the results of interactions between the Laporo tribe and other tribes.

Based on these findings, if there is still discriminatory treatment of the Laporo tribe, it is part of the past that was actually formed by the division of functions of the work (the Laporo tribe was given the task of being a manual laborer in agriculture) which later formed the notion that they were slaves based on the law especially customary law from the Kingdom of Buton.

To ensure that Buton Regency is free from human rights violations, the increased status of Human Rights Care of Buton district into a Human Rights District will bridge the protection of human rights in Buton and especially those who are marginalized and who experience discrimination.

\section{Bibliography}

$\underline{\text { Books }}$

Antonio Pradjasto H. (2015). Panduan Kabupaten dan Kota Ramah Hak Asasi Manusiajakarta Selatan: Infid

Badja, S. (2012). The Sleeping Giant Buton Raya; Isyarat Ilmiah Menguak Tabir Tujuh. Makasar: Puslitbang Witaris Unhas

Maula, M. J. (2011). Kesepakatan tanah Wolio: ideologi kebhinekaan dan eksistensi budaya bahari di Buton. Program Pascasarjana Departemen Antropologi Fakultas Ilmu Sosial Dan Ilmu Politik Universitas Indone.

Rawls, J. (1999). The Law of Peoples in Samuel Freeman, ed., Collected Papers Cambridge: Harvard University Press

Schoorl, J. W. (2003). Masyarakat, Sejarah, dan Budaya Buton. Jakarta: Penerbit Jambatan-Perwakilan Kitlv

Sparringa, D. T. (2003). Multikulturalisme Dan Multi Perspektif di Indonesia. In Surabaya: Forum Rektor Simpul Jawa Timur.

Tahara, T. (2014). Melawan stereotip: etnografi, reproduksi identitas, dan dinamika masyarakat Katobengke, Buton yang terabaikan. Jakarta: Kepustakaan Populer Gramedia. 


\section{Journals and Papers}

Pager, D., \& Shepherd, H. (2008). The sociology of discrimination: Racial discrimination in employment, housing, credit, and consumer markets. Annu. Rev. Sociol, 34, 181-209. https:// doi.org/10.1146/annurev.soc.33.040406.131740

Suparlan, P. (2014). Menuju masyarakat Indonesia yang multikultural. Antropologi Indonesia.

\section{Dissertation}

La Ode Abdul Munafi. (2016). "Etnografi Kaomu; Strategi Bertahan Kelompok Bangsawan dalam Struktur Masyarakat Buton", PhD Dissertation: Universitas Hasanuddin

\section{Newspaper}

La Ode Abdul Munafi. “Memahami Esensi Sara Pataanguna dalam Undang-Undang Martabat Tujuh Buton". Harian Buton Pos.

\section{Website}

United Nations Human Right: Office of the High Commisioner. International Human Rights Law. Retrieved From https://www.ohchr.org/en/professionalinterest/pages/internationallaw.aspx

Nindhitya Nurmalitasari. (2018). INFID Apresiasi Pembentukan Komisi HAM Daerah Pertama di Indonesia. International NGO Forum on Indonesian Development. Retrieved From https://www.infid.org/infid-apresiasi-komisi-ham-daerahpertama-indonesia/.

Wikipedia. Retrieved From https://id.m.wikipedia.org/wiki/Kabupaten_Buton

\section{Interviews}

Tasrim, S.Pd., M.Pd. (Buton Academics) in Saragi Village, Pasarwajo District., April 20, 2019, 10 AM

Drs. Amruddin (Head of Pasarwajo Sub-District) at Pasarwajo Sub-District Office, April 20, 2019, 20: 15 PM

La Makki (Sejarawan Buton) at Kelurahan Kambula-Mbulana, April 20, 2019, 21:05 PM.

Drs. Murtaba Muru, M. A. (Chair of the Laporo Tribe Family Harmony) in LinggeLingge Village, April 21, 2019, 21:00 PM

\section{$\underline{\text { Law }}$}

Law Number 39 of 1999 concerning Human Rights

Law No. 40 of 2008 concerning the Elimination of Racial and Ethnic Discrimination

Minister of Law and Human Rights Regulation of the Republic of Indonesia Number 25 of 2013 concerning Amendments to Regulation of the Minister of Law and Human Rights Number 11 of 2013 Concerning Criteria for Districts / Cities Caring for Human Rights.

Law Number 23 Year 2014 concerning Regional Government (Regional Government Law

Presidential Regulation 75 of 2015 states that Ministers, heads of institutions, governors, and Regents / Mayors are responsible for implementing RANHAM 